DOI: $10.1515 /$ aa-2017-0011

\title{
Culture in advertising and advertising in culture: Communication,
} translation, representation

\author{
Edita Gromová - Daniela Müglová - Emília Perez
}

Edita Gromová is a professor at the Department of Translation Studies, Faculty of Arts, Constantine the Philosopher University, Nitra. Her main research interests are translation studies, translation theory and didactics. She is author of numerous publications in the field of translation studies and translation pedagogy including Interpretácia $v$ procese prekladu ('Interpretation in the Translation Process') in 1996 and Teória a didaktika prekladu ('Translation Theory and Didactics') in 2003 and co-author of Kultúra - Interkulturalita Translácia ('Culture - Interculturality - Translation') in 2005.

Daniela Müglová is a professor at the Department of Translation Studies, Faculty of Arts, Constantine the Philosopher University, Nitra and one of the founders of the first translation studies study programmes in Slovakia. She primarily deals with the theoretical, methodological and didactic aspects of interpreting and the cultural dimension in translation transfer. Along with many articles published in Slovakia and abroad, she has authored a number of monographs. She is also the co-author of Communication, Interpretation, Translation, an interpreting textbook used all around Slovakia.

Emília Perez is Head of Department and lecturer at the Department of Translation Studies, Faculty of Arts, Constantine the Philosopher University in Nitra, Slovakia. Her main field of interest is audiovisual communication and its projection in translation. In the academic year 2011/2012, she initiated the systematic specialized training of students in the field of audiovisual translation at the Department of Translation Studies, CPU Nitra. Besides her academic activities she also deals with audiovisual translation in practice, cooperating with several domestic and foreign film festivals, agencies and dubbing studios.

\begin{abstract}
:
The authors of the paper focus on the intercultural dimension in the translation of advertising texts, attempting to compare and illustrate the influence of cultural elements upon advertising text-creation in American, German and Slovak cultural spaces. Reflecting the social, psychological and cultural aspects of translation transfer, they survey the tension between the domestic and the foreign and consequent choices in translation strategy. They present tendencies observed across a span of almost two decades in the translation of advertising texts into Slovak and provide possible explanations for their development.
\end{abstract}

Marketing communication is in itself a highly interesting phenomenon both in its expression and translational aspect, and advertisings texts can also be seen as a pronounced example of cultural determination - even despite the intense pressure of cultural-civilizational 
processes, primarily of globalization and transculturalism. Before approaching specific analyses, we deem it necessary to plant the observed topic into a wider culturological context and clarify why intercultural differences in the transfer of this text type play such an important role and why the translator is often forced to utilize substitutive (naturalizing) or creolizing translation strategies, balancing the tension between domestic and foreign. Our theoretical observation is based on the postulates of the symbolic interpretative anthropology of Clifford Geertz, which forefronts the semiotic concept of culture. We also utilize the classification of intercultural dimensions and intercultural orientations as understood by Hofstede, Torpenaars and Hall as our terium comparationis for introducing the translation of advertising discourse. In the context of our investigation, the semiotic approach is incorporated, as it provides the possibility to observe the advertising message from multiple perspectives, thus allowing for from the standpoint of cultural determination - evaluation not only of the verbal and non-verbal aspects of the utterance but also the level of culturally determined connotations, presuppositions, ways of thought, or, summarily, mentality.

The semiotic approach is founded on the fact that signs carry a certain propositional content independent of cultural determinations, from which, however, different meanings may be formed in different contexts. Posner adds (1991, p. 53) that in a culture there exist also concepts based on notions which need not be lexicalized, i.e. there are concepts without objects existing in reality. Even such non-lexicalized concepts constitute a part of culture. These are known as mentifacts, which become the carriers of interaction if there is a sign (signifier), the significance of which is a mentifact (Hennecke, 1999, p. 42). Correlation between signifier and significance is known as code. It can be therefore gathered that every mentality can be understood as a sum of codes (ibid.). The type of code, their number and elaboration are decisive for mentality, and, thus, for the type of function of values, ideals, norms and ways of thought. Mental culture is nothing other than a system of sign conventions common to a single culture. These sign conventions then guide social behaviour and determine the meanings and functions of artefacts in a given culture (Posner, 1991, p. 53). Posner understands artefacts as everything "that is a result of conscious action" (ibid, p. 45). Texts, understood in a broad sense as all coded and intended artefacts, also belong here. Some semioticians go even further and define culture as a set of texts (ibid). Posner correlates the stated premises and states: "If a society is a set of sign users, civilization a set of texts and mentality a set of codes, than these three systems are inevitably linked, as users of signs are dependent on codes if they wish to understand texts" (ibid). Henneke highlights that the deciphering of artefacts by different societies and cultures is not identical, with differing functions thus attributed to them in different contexts (1991, p. 53). 
This is because there are certain parallels between interlingual and intercultural (mis)understandings. Their difference dwells in the fact that culture is a much more layered and complicated system, with language only a certain part of it, a materia in which the culture is reflected. Interlingual (mis)understandings are most clearly explained by prototype semantics - interlingual understanding is possible because categorization of individual and collective experience manifested in lexis shares a common core (prototype) and diffusive, culturally determined edges (fuzzy edges).

To use an analogous terminology, certain prototype cores, common intersections of cultures, can also be seen at the level of entire culture systems. This is because they were formed gradually, during the entire historical genesis, within conquering, commercial, ideological, scientific, cultural and other contacts. They were caused by migrations of nations and, recently, by civilizational-cultural processes. This can be seen in the existence of cultures sharing a multiplicity of codes and therefore possessing "a large intersection of mental cultures" (ibid). At the same time, however, there are no two cultures that would demonstrate an absolute overlap of code repertoire. This is why there always exist codes, or mentalities, on the periphery of the intersection, which serve as sign carriers only in one culture and can be expressed by various signifiers (signs) (ibid, p. 43). These culturological "fuzzy edges" can relate to many mentifacts. In the context of advertising text analysis, these are non-lexicalized and nonvisualized presuppositions (such as colour and number symbolism, etc.), as the content volume of presuppositions differs between cultures. These are strikingly relevant in international advertising production. For global advertising with a high degree of standardization, this means that the advertising message, or its persuasive effect, varies partially even among cultures with significant mental overlap. If the sign conventions differ significantly, a misunderstanding of the intended advertising message may occur, leading to a failure of marketing communication in most extreme cases. There is a whole range of examples of such failures known from marketing practice, caused by a copywriter or translator not realizing the existence of intercultural differences.

\section{The cultural aspect in advertising discourse in Slovakia, USA and Germany}

Recently, the field of intercultural psychology has been paying significant attention to the comparison of psychosocial characteristics of cultures, ethnic groups and nations. Among the prioritized areas of comparative research in social psychology lies the value orientation of the individual cultures. Pavel Hartl and Helena Hartlová define a value as an "attribute, which an individual ascribes to a certain object, situation, event or activity in relation to one's 
satisfying of needs and interests. Values are created in the socialization process and are a part of social consciousness. They are organized hierarchically, according to their importance, into value systems while a value system defines the most general stances, lifestyle and morals of every person" (2000, p. 192). Obviously, the socialization processes creating such systems are closely related to the cultural environment they arise in, which is well reflected in the intercultural comparison of value systems by Dutch sociologist Geert Hofstede (1991). At the end of the 1960s and in the first years of the following decade, Hofstede carried out a vast research project on value orientations for IBM. Despite certain critical reservations about the methodology of this research, his intercultural comparison holds an indisputable validity, and that is due to the quantity of test subjects $(116,000)$, representation of countries (50) and comprehensiveness of the questionnaire (63 questions). Furthermore, Hofstede's research methodology was replicated by American psychologist Ashleigh Merrit in 1993-1997 who, in essence, verified his conclusions, namely the definition of five basic intercultural dimensions:

- $\quad$ power distance (strength and social hierarchy) - the degree of expectation of unequal power distribution;

- $\quad$ uncertainty avoidance - the degree of the threat perceived by members of a given society in ambiguous or unknown situations ;

- individualism - collectivism - the degree of dependence of an individual on the collective and the degree of freedom of one's own initiative;

- $\quad$ masculinity - femininity - the representation and influence of male and female elements in the value system of a society;

- long-term - short-term orientation - preference of attributes such as persistence, tenacity, willingness to submit to temporary (typically economical) restrictions in favour of long-term goals.

This classification characterizes the surveyed countries according to the presence and degree of the dimensions and although it might seem to be of an a priori, even tendentious character at first glance, if we temporarily accept the specified criteria as true and apply them to translation, perceiving it as an intercultural transfer, interesting results can be derived.

In our paper we contrastively compare the advertising discourse in Slovakia, USA and Germany. From the standpoint of intercultural dimensions and orientations, we can observe basic, culturally determined text-production tendencies, since the culture manifests itself in language. The USA is, from this standpoint, characterized by low power distance, individualism, masculinity, neutrality and low-context communication. American advertising shows tendencies towards brevity, simplicity and pragmatism; it addresses the potential 
consumer directly; the power distance index manifests itself in informal forms of addressing the consumer - a fact which is, ultimately, also linked to English's absence of T - V distinction in forms of address; as an individualist culture, it often utilizes so-called hard-sell strategies in advertising, which frequently lead to a heightened aggressiveness in marketing campaigns. This is related to the value scale of this culture, in which achievement values stand on the highest rung. Additionally, the USA is one of the countries with a short-term orientation, i.e. it focuses on near goals and immediate results. The representation of figurative expressive means is neither as high nor varied as in Slovak culture, with onomatopoeic and rhythmic elements almost never utilized. Intercultural differences are also reflected in the somatic language. For individualist cultures, direct eye contact is typical, as it symbolizes trust. If a person appears in US adverts as a medium promoting a product, our survey shows they will be looking directly into the eyes of the potential consumer.

From the standpoint of the intercultural dimension, Germany is a country that features low power distance, is individualist, masculine and neutral, and tends towards low-context communication. In German slogans, allusions to gnomes and cultural traditions are present relatively often. Product characteristics are developed precisely, with technical details in body copy. In forms of address, formality through using the formal V-form of address is prevalent. Advertising appeal is focused on highlighting benefits that suggest the reliability and credibility of the product. Local patriotism is often accentuated, e.g. by means of colour symbolism or using dialectic expressive means. A tendency towards the persuasive influence of the rational aspect of the personality is dominant. The presence of expressive means of expression is more widespread than in US advertising discourse, but their emotional charge is often weaker than in Slovak advertising.

In terms of the intercultural dimension, Slovakia is a country with a high power distance index, tendencies towards collectivism, marked masculinity, high emotionality and highcontext communication. In the dimension of power distance, behaviour patterns of Slovaks correlate with Slovakia's high index (79). Slovaks approach those of higher social status with respect and admiration, which either turns into a negative attribute - envy, or is modified into a desire to improve one's own social status. Power and wealth are outwardly manifested in ownership of luxury goods, holidays in exotic destinations, and special benefits in the services of banks and other institutions. Therefore, the Slovak commercial market uses the desire to "visually" achieve higher social respect through ownership of luxury goods as a means of promotion of brand products of renowned companies and exclusive services to a greater extent than cultures with low power distance (e.g. Austria). In advertising appeals, media celebrities 
with high social status play a relatively significant role. Additionally, Slovak advertising discourse tends to address the consumer in the more polite V-form. In the intercultural dimension of uncertainty avoidance, Slovak culture (with an index of 37) does not perceive danger and is willing to undertake risk. This may be the reason why the advertising of loans from non-banking entities (despite a real risk of insolvency and repossession of property, cases of which often resonate in the media) are more effective than in countries with high uncertainty avoidance index, such as the UK. For the text-creation of the advertising message, "lightening" is typical, i.e. elements of humour and entertainment are more frequently used.

The taxonomy of individualist $\mathrm{v}$. collectivist cultures deals with the degree of dependence of an individual on the collective. Hofstede defines individualism as a stance in which: "[...] everyone is expected to look after him- or herself and his or her immediate family" and collectivism as a stance in which "people from birth onward are integrated into strong, cohesive in-groups, which throughout people's lifetime continue to protect them in exchange for unquestioning loyalty" (Hofstede, 2010, p. 92). Slovakia, with an index of 48, leans towards collectivism, as opposed to Anglophone and Germanophone cultures. Forms of address in Slovak advertising slogans more often than in individualist cultures stress belonging to a gender or social group and utilize the V-form in such cases, using this approach to emotionally affect the consumer through their sense of belonging to a group. This phenomenon manifests itself also in modification of pre-existing slogans, e.g. In L' Oréal's I'm worth it, the established form of which ( $\mathrm{Ja}$ za to stojím, a literal translation using the singular form) is often complemented by the expression My za to stojíme (We are worth it - as in we women).

The relation masculine v. feminine, hinted at in the previous example, is evident in division of male (man as provider for the family) and female (woman as caretaker for the family) roles in society and the preference of male or female value orientation associated with it. Masculinity is reflected in such attributes as competitiveness, assertiveness, successfulness, focus on material well-being, career growth, etc. Femininity, in turn, manifests itself in focus on quality of life, reinforcement of the family environment, social solidarity, equivalence, etc. Slovakia is the most masculine culture in the entire Central Europe. It is necessary to take this aspect into account in the creation of advertising slogans, where it typically takes the form of hyperbolization and promises to provoke greater expectations. At the same time, it is also necessary to take into consideration the entirety of the communication context, i.e. the addressee of the advert, their anticipated social status and level of education, the graphic design and visuals of the advert, the product that is being advertised and so on. The character of the product signalizes in advance which aspect of the value orientation of the consumer the advertisement 
producer can count on (health, security, looks, financial benefit, etc.) and, simultaneously, whether to appeal to the consumer's rational or emotional decision-making.

This last criterion is directly linked with the intercultural orientation of emotive $v$. neutral cultures. This relation is vital for the production as well as for the intercultural transfer of advertising discourse, as it defines the base tendencies in the choice of promotion and translation strategies in order to achieve the desired effect. While Anglophone and Germanophone countries have neutral cultures, Slovakia, just as with all Slavic cultures, has an emotive culture. In advertising communication, the persuasive aim is typically achieved by a functional and creative connection between the emotional and rational aspects of the human personality. Eva Vopálenská states that "emotional messages are more memorable than informative appeals, because they are captured globally, in their entirety and, at the same time, they bind a certain energetic potential to them, even if the information itself is seemingly forgotten" (2009, p. 40). The main asset of rational messages, on the other hand, is their provision of information and, more importantly, provision of the argumentative basis for selection and purchase of a specific product. In the translation of advertising discourse, the relation between emotionality vs. neutrality dictates the dominance of the representation of either emotional or rational aspect of the advertising message, reflecting the preferences of a given culture. The emotionality of Slovak culture manifests itself in the preference of emotive appeals, and frequent use of figurative means of expression and humour. In addition to the listed intercultural characteristics, it is important not to forget the differences between low- and highcontext cultures. While low-context cultures express themselves directly, not relying on additional interpretation of the implied verbal or non-verbal signs, high-context cultures, such as Slovakia, seem to attribute a wider connotation dimension and more space for receiver interpretation to means of expression, i.e. a large amount of information only implies, sometimes even intentionally obscures, a direct statement, or leaves the statement open to interpretation. This may be the reason why adverts in the form of short stories or "mini dramas" tend to be popular.

\section{Cultural specifics in translation of advertisements into Slovak}

As translation activity reflects the state of society, including all the civilization-cultural processes taking place within it, from the standpoint of translation strategies two tendencies (respectively, two temporally determined development phases) have been observed in Slovakia as regards to the translation axis naturalization - creolization - exotization. The first phase aligns with the period shortly after the changes of the Velvet Revolution and lasting until 
approximately 2005. In this phase, the exotizing strategy dominates in practically all massmedia genres. Our survey reveals that Slovak translators prefer retention in the transfer of foreign exotically marked elements. A similar tendency was observed in analysis of translation strategies in the translation of advertising texts into Czech and Slovak (Jettmarová, 1998, 1999; Griač, 2004). In the translation of these texts into Czech and Slovak, a tendency was revealed towards assimilation of foreign elements and significant interference at all textual levels. What does this signify?

In broader sociocultural relations, in some cultures a certain defence can be perceived of traditions, culture and thought from invasion of the foreign - about a greater closedness of cultural systems and defence of identity. These strategies reflect the translation tradition of these cultural communities within their own cultural space, which has its own geopolitical and historical relations. On the other hand, Slovak translations are a testament to the openness of this cultural space towards foreign influence. Tolerance towards assimilation of elements of foreign cultures is generally significant in Slovakia, but was more than evident in the discussed period. This is likely a result of multiple factors:

1. The aforementioned tendency could be interpreted as proof of Lambert's statement that less dominant societies tend to "import" the foreign without great barriers, also as a certain statement of fashionability (see: Lambert 1993). In a given sociocultural context, the "desire for fashionability" or "fascination by foreignness" is understandable once we realize that Slovakia was the epicentre of turbulent changes during and shortly after the revolution. These changes can be summarized under the umbrella of the fall (both physical and metaphorical) of the Iron Curtain, an escape from isolation, the process of opening up to the world, and freedom of movement and speech.

2. A preference for the exotizing strategy frequently signifies an absence of genre. As the advertising genre was absent in Slovakia in the form it had in Western countries, a historically common situation could arise, when "...a translation fulfills a function of enriching the domestic culture and language - in such a situation a more literal translation is preferred, with its interferences, exotization, by which a language changes and modernizes itself: naturalization and the requirement of the same effect moves to the background" (Jettmarová, 1998, p. 36).

3. Frequent literal translation could also be caused by pragmatic reasons, i.e. a lack of professionality on the part of translators, who, for commercial reasons, often insisted on literalness in translation. 
In opposition to the first phase, where text structure, and appeal strategies and language were incorporated from the original into advertising translation, the second phase demonstrates new tendencies. A gradual but evident shift takes place, a form of exotizing to creolizing and, sporadically, the naturalizing principle. Naturally, this trend is also influenced by multiple factors. "Fascination by foreignness" was slowly saturated and the pressure of the "foreign" provoked even conscious "defensive" reactions, i.e. efforts to differentiate oneself from the "foreign". This phenomenon becomes even more explicit in advertising for domestic products. A clear example are spots for Zlatý Bažant (in English-speaking countries sold as Golden Pheasant) - a domestic brand of beer. Informative translations of the transcripts are provided in full for illustrative purposes (in more detail cf. Gončarova, 2009, p. 563):

\section{Advertisement 1:}

I am woken up by British pop music from a Taiwanese alarm clock. I put on Italian jeans, a Tshirt made in China. I take my Hungarian Vizsla for a walk and go to work. My French boss requires German punctuality, even though my job is all Greek to him. I finish eating a Norwegian fish with Greek salad and still have room for more, but at work I can only take a Brazilian coffee made on Russian gas. After a practice of Japanese judo, I finally park my Korean car and have a Slovak beer. I meet the entire world every day, but in the evening, I am looking for something ours. Golden Pheasant-global Slovak beer.

\section{Advertisement 2:}

To have a system and be good at it, that is German, but to not have a system and be good at it, that is Slovak. To not know where Slovakia is is American. To know where Slovakia is is Slovak. To have a thousand bucks in your pocket and pretend you only have twenty, that is Czech, but to have a twenty and pretend you have a thousand, that is Slovak. To build a particle accelerator is European. To not hurry anywhere is Slovak. To want to borrow from everybody, that is Greek. But to not want to lend to Greece, that is Slovak. To marry a Slovak woman, that is English, Italian, Austrian and United-Arab-Emiratean, but to marry a Slovak man is Slovak. To have an exceptional gastronomy is French, but to have an exceptional appetite is Slovak. To go out with friends in the evening is Slovak and to have a Pheasant with them is global: Golden Pheasant - global Slovak beer. 


\section{Conclusion}

The authors of this paper tried to provide a brief inquiry into the translation of advertising texts from the point of view of the sociocultural, "Lotmanesque" opposition DOMESTIC FOREIGN and its realization in translation techniques. Based on Hofstede's classification of five basic cross-cultural dimensions (power distance, uncertainty avoidance, individualism collectivism, masculinity - femininity, and long-term - short-term orientation), the relationships between cultural values and translation strategies expressed in translating advertising texts in Slovakia were analysed. Focusing on the development in the 1990s and first two decades of the 21 st century, Slovak translations show a tendency towards a certain cultural openness of the cultural space and a tolerance towards assimilation of elements of foreign cultures in the earlier periods, presently resulting in more modern efforts to effectively differentiate the domestic from the foreign. We can also observe that the advertising genre became integrated into the Slovak cultural tradition and translators started to be aware of the role intercultural differences play in persuasive message transfer. This has been proven by multiple results of comparative research realized in qualifying theses on a valid corpus of Slovak, American and German advertisements conducted at the Department of Translation Studies CPU in Nitra (see Aszalayová 2011; Fúrová 2015; Jankajová 2016; Tóth 2016; Kažimír 2017).

\section{References}

Aszalayová, L. 2011. Pomer anglicizmov a amerikanizmov pri preklade neliterárnych textov. Nitra: Univerzita Konštantína Filozofa v Nitre. [doctoral thesis].

Charfaoui, E. 2014. Komunikativno-pragmatické a lingvokultúrne charakteristiky reklamného textu. Bratislava: Univerzita Komenského.

Fúrová, M. 2015. Špecifiká prekladu reklamných sloganov z jazykového a sociokultúrneho hladiska. Nitra: Univerzita Konštantína Filozofa v Nitre. [diploma thesis].

Frieling, H. 1981. Farbe hilft verkaufen. Farbenlehre und Farbenpsychologie für Handel und Webung. Göttingen-Zürich.Muster-Schmidt Verlag.

Geerz, C. 2000. Interpretace kultur. Praha: Sociologické nakladatelství.

Griač, D. 2004. Preklad reklamných textov z angličtiny do slovenčiny. Nitra: Univerzita Konštantína Filozofa v Nitre. [diploma thesis].

Gromová, E. - Müglová, D. 2005. Kultúra - Interkulturalita - Translácia. Nitra: Filozofická fakulta UKF.

Hall, E. T. 1976. Beyond Culture. New York: Anchor Books.

Hartl, P. - Hartlová, H. 2000. Psychologický slovník. Praha: Portál.

Hofstede, G. 1991. Cultures and organizations: software of the mind. London: McGraw-Hill. Hennecke, A. 1999. Im Osten nichts Neues? Eine pragmalinguistisch-semiotische Analyse ausgewählter Werbeanzeigen für Ostprodukte im Zeitraum 1993 -1998. Frankfurt am Main: Peter Lang. 
Lambert, J. 1993. "In Quest of Literary World Maps.” In: Kittel, H. - Frank, A. (eds.). Interculturality and the Historical Study of Literary Translations. Berlin: Erich Schmidt, 1993, pp. 133-44.

Lotman, Ju. M. 1969. “O metajazyke tipologičeskich opisanij kul'tury.” In: Lotman, Ju. M. (ed). Trudy po znakovych sistemach IV. Tartu: Тартуский университет, pp. 460-477.

Jankajová, I. 2016. Komparativna analýza figurativnych výrazových prostriedkov v reklamných textoch elektronických médii v nemecko-slovenskej jazykovej mutácii. Nitra: Univerzita Konštantína Filozofa v Nitre. [diploma thesis].

Jettmarová, Z. 1998. "Úloha kontextu v překladu reklamy do češtiny: dynamika výchozí překladatelské normy.” In: Rády, A. (ed.). 14 krát o překladu. Praha: JTP, pp. 43-47.

Kolman, L. 2001. Komunikace mezi kulturami. Psychologie interkulturních rozdilü. Praha: Česká zemědělská univerzita.

Merrit, A. 2000. "Culture in the Cockpit: Do Hofstede's Dimensions Replicate?" In Journal of Cross-Cultural Psychology, vol. 31, no. 3, p. 17.

Posner, R. 1991. "Kultur als Zeichensystem. Zur semiotischen Explikation kulturwissentschaftlicher Grundbegriffe." In Dietich, A. - Dietrich, H. (eds.).: Kultur als Lebensweisheit und Monument. Frankfurt am Main: Fischer, pp. 36-74

Smith, P. B. - Dugan, S. - Trompenaars, F. 1996. "National culture and the values of organizational employees a dimensional analysis across 43 nations." In Journal of crosscultural psychology, vol. 27. no.: 2, pp. 231-264.

Tóth, M. 2016. Diachrónny a synchrónny pohl'ad na globalizačné, glokalizačné a lokalizačné prekladatel'ské stratégie $v$ transfere elektronických reklamných sloganov. Nitra: Univerzita Konštantína Filozofa v Nitre. [diploma thesis].

Trompenaars, F. - Hampden-Turner, C. 1996. Riding the waves of culture: Understanding Cultural Diversity in Business. London: Nicholas Brealey Publishing Limited.

Vopálenská, E. 2011. Jazyk a štýl reklamy 2. Bratislava: Univerzita Komenského.

Žilková, M. 2006. "Vplyv globalizácie na mediálnu kultúru." In: Žilková, M (ed.). Vplyv globalizácie na mediálnu kultúru. Nitra: Ústav literárnej a umeleckej komunikácie UKF, pp. 13-23.

Edita Gromová

Department of Translation Studies

Faculty of Arts

Constantine the Philosopher University in Nitra

Štefánikova 67, 94974 Nitra, Slovakia

egromova@ukf.sk

Daniela Müglová

Department of Translation Studies

Faculty of Arts

Constantine the Philosopher University in Nitra

Štefánikova 67, 94974 Nitra, Slovakia

dmuglova@ukf.sk

Emília Perez

Department of Translation Studies

Faculty of Arts

Constantine the Philosopher University in Nitra

Štefánikova 67, 94974 Nitra, Slovakia

eperez@ukf.sk 


\section{Acknowledgement}

This paper is a result of the VEGA project No.: 2/0200/15 Preklad ako súčast' dejín kultúrneho priestoru II. (Translation as a Part of History of Cultural Space II). 